\title{
Innoveren om beter te leren
}

Citation for published version (APA):

Dolmans, D. H. J. M. (2012). Innoveren om beter te leren. Maastricht University. https://doi.org/10.26481/spe.20120627dd

Document status and date:

Published: 27/06/2012

DOI:

10.26481/spe.20120627dd

Document Version:

Publisher's PDF, also known as Version of record

\section{Please check the document version of this publication:}

- A submitted manuscript is the version of the article upon submission and before peer-review. There can be important differences between the submitted version and the official published version of record.

People interested in the research are advised to contact the author for the final version of the publication, or visit the DOI to the publisher's website.

- The final author version and the galley proof are versions of the publication after peer review.

- The final published version features the final layout of the paper including the volume, issue and page numbers.

Link to publication

\footnotetext{
General rights rights.

- You may freely distribute the URL identifying the publication in the public portal. please follow below link for the End User Agreement:

www.umlib.nl/taverne-license

Take down policy

If you believe that this document breaches copyright please contact us at:

repository@maastrichtuniversity.nl

providing details and we will investigate your claim.
}

Copyright and moral rights for the publications made accessible in the public portal are retained by the authors and/or other copyright owners and it is a condition of accessing publications that users recognise and abide by the legal requirements associated with these

- Users may download and print one copy of any publication from the public portal for the purpose of private study or research.

- You may not further distribute the material or use it for any profit-making activity or commercial gain

If the publication is distributed under the terms of Article $25 \mathrm{fa}$ of the Dutch Copyright Act, indicated by the "Taverne" license above, 


\section{Maastricht University}

\section{Prof. dr. Diana H.J.M. Dolmans}

Faculty of Health, Medicine and Life Sciences

\section{Innoveren om beter te leren}

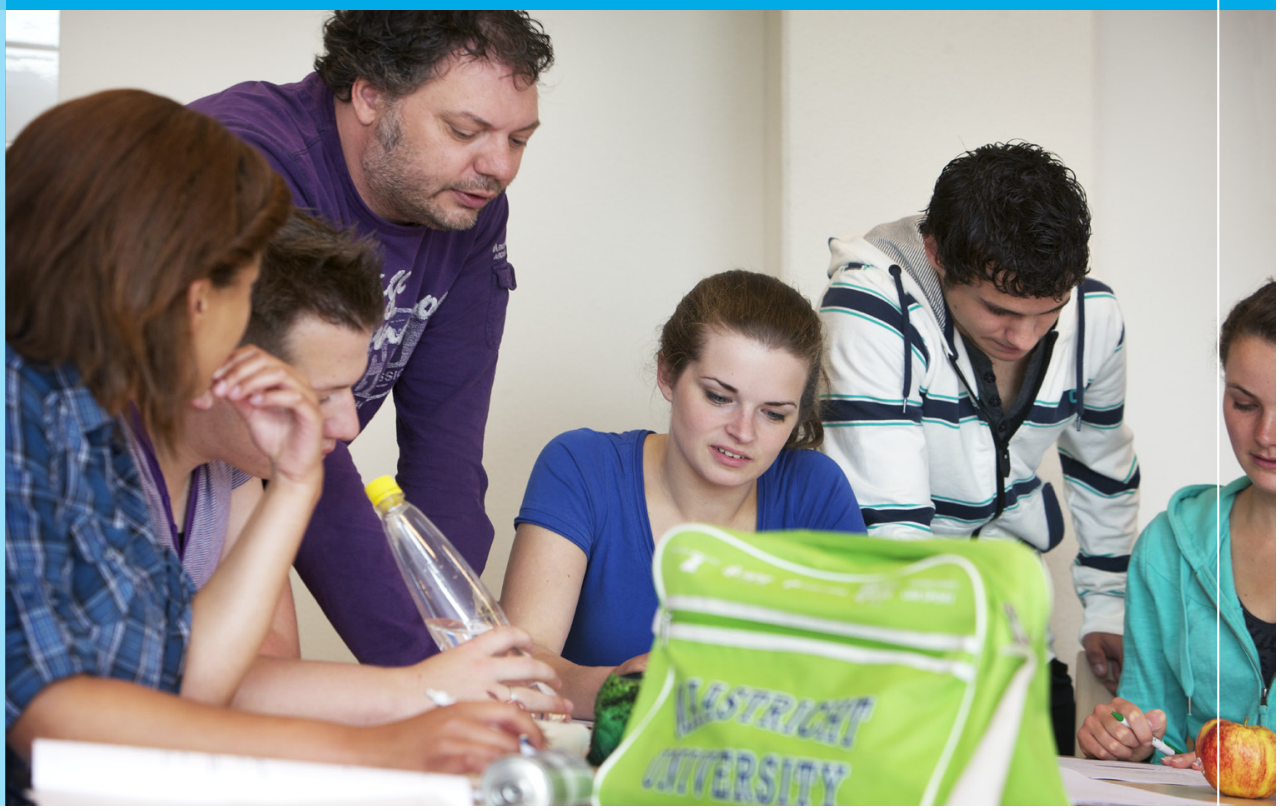


Innoveren om beter te leren 
Faculty of Health, Medicine and Life Sciences

\section{Colofon}

Ontwerp en print: Océ Business Services, Maastricht

ISBN: 9789056813932

NUR: 870

Alle rechten voorbehouden. Niets uit deze uitgave mag worden verveelvoudigd, opgeslagen in een geautomatiseerd gegevensbestand of openbaar gemaakt worden, zonder voorafgaande schriftelijke toestemming van de auteur of uitgever. 


\section{Innoveren om beter te leren}

Inaugurele rede

Maastricht, 27 juni 2012

Faculty of Health, Medicine and Life Sciences

Prof. dr. Diana H.J.M. Dolmans 


\section{Innoveren om beter te leren}

Mijnheer de Rector Magnificus, geacht College van Bestuur, geachte Decaan, beste collega's, vrienden, familie en andere aanwezigen. Vandaag mag ik $u$ allen toespreken met deze inaugurale rede.

\section{Inleiding}

Onderwijs is van groot belang voor onze samenleving. In een wereld die snel verandert en waarin vele complexe problemen opgelost moeten worden, behoort onderwijs een goede voorbereiding te bieden op een leven lang leren, op een zinvolle deelname aan de maatschappij en op een succesvolle beroepsloopbaan. Maar, hoe kun je leren optimaal bevorderen? Hoe richt je een leeromgeving in die lerenden voorbereidt op een leven lang leren en een succesvolle beroepsloopbaan? Binnen mijn vakgebied, de onderwijswetenschappen, proberen we die vragen te beantwoorden. We doen onderzoek om leeromgevingen beter te begrijpen en te verklaren met als doel het onderwijs te optimaliseren en daarmee aan te zetten tot beter leren. Ik heb me de afgelopen jaren beziggehouden met onderzoek op het gebied van innovatieve leeromgevingen in het algemeen en probleemgestuurd onderwijs in het bijzonder. Probleemgestuurd onderwijs is een onderwijsleeromgeving die al meer dan 35 jaar aan deze universiteit wordt toegepast in verschillende onderwijsprogramma's. In de afgelopen jaren is er gewerkt aan het optimaliseren van probleemgestuurd onderwijs en nog steeds wordt hieraan gewerkt in deze instelling. In deze rede beantwoord ik de vraag wat we tot nu toe weten over leren en over probleemgestuurd onderwijs en wat nog verder onderzoek behoeft. Ik zal betogen dat probleemgestuurd onderwijs goed aansluit bij hedendaagse inzichten over leren, maar ook dat permanente innovatie van probleemgestuurd onderwijs nodig is om aan te zetten tot beter leren.

De opbouw van mijn rede is als volgt. In het eerste deel ga ik in op de vraag wat leren is. Hierbij komen theorieën over leren en hedendaagse leerprincipes aan de orde. In het tweede deel ga ik in op de relatie tussen probleemgestuurd onderwijs en hedendaagse leerprincipes. In het derde deel vat ik samen wat er bekend is uit onderzoek op het gebied van probleemgestuurd onderwijs. In het vierde deel bespreek ik de problemen die ervaren worden met deze onderwijsvorm en 
welke aanpassingen dit vereist in de leeromgeving. In het vijfde deel presenteer ik mijn onderzoeksagenda. Tot slot vat ik de belangrijkste conclusies samen.

\section{Deel 1: Leren en leerprincipes}

Leren is een complex begrip. Als ik $u$ vraag wat $u$ verstaat onder leren en hoe $u$ zelf het beste leert en $u$ vraag daarover met uw buurman of buurvrouw in deze zaal te overleggen, dan zult $u$ ontdekken dat dit allerlei verschillende antwoorden oplevert. De een zal zeggen dat hij het beste leert door goed te luisteren, te lezen, aantekeningen te maken en samen te vatten. Een ander zal wellicht zeggen dat zij het beste leert door een ander vragen te laten stellen, door met anderen te discussiëren, door samen met anderen een schema of een samenvatting te maken en door samen met anderen te werken aan de oplossing van een probleem. De een zal leren vooral benaderen als een individuele activiteit, terwijl de ander zal benadrukken dat er vooral veel van elkaar geleerd kan worden. Over de wijze waarop leren het beste bevorderd kan worden bestaan uiteenlopende theorieën, die verschillende aspecten van leren benadrukken. Tegenwoordig wordt veelal uitgegaan van constructivistische theorieën over leren. Hierbij wordt een globaal onderscheid gemaakt tussen het cognitief constructivisme en het sociaal constructivisme. Volgens het cognitief constructivisme is leren vooral het mentaal actief verwerken van informatie en het koppelen van nieuwe informatie aan reeds bestaande kennis. Volgens het sociaalconstructivisme is leren vooral het opbouwen van kennis, waaraan betekenis wordt gegeven door met anderen te interacteren (Hean et al., 2009). De ene theorie benadrukt vooral het individuele leren, de andere theorie legt de nadruk op het samen met anderen leren.

Het cognitief constructivisme vindt zijn wortels bij Piaget. De Zwitserse psycholoog, Piaget (1896-1980) ging er vanuit dat leren verloopt volgens een aantal ontwikkelingsstadia, waarbij eerst de motoriek, daarna de taal en als laatste het abstracte denken en redeneren tot ontwikkeling komt. De grondlegger van het sociaal constructivisme, de Russische psycholoog Vygotsky (1896-1934), ging ervan uit dat leren plaatsvindt door te interacteren met anderen bij het werken aan betekenisvolle taken. Ondersteuning door een ander kan de lerende naar een hoger niveau brengen: de zone van nabije ontwikkeling. Wordt het hogere 
niveau eenmaal beheerst, dan kan de ondersteuning weer afgebouwd worden. Het sociaal constructivisme legt dus de nadruk op sociale interactie bij het leren.

Tegenwoordig worden velerlei metaforen gebruikt om duidelijk te maken dat leren een dynamisch transformatieproces is. Leren is enerzijds een proces van actieve verwerving van kennis; de "knowledge acquisition" ofwel "kennisverwervings" metafoor. Hierbij wordt leren vooral gezien als een individueel proces. Er is sprake van leren als er veranderingen optreden in de kennis van de lerende. Maar, leren is anderzijds ook een proces van participeren en interacteren met anderen; de "participatie" of "interactie" metafoor. Hierbij wordt het belang van de sociale omgeving benadrukt. Deze twee metaforen worden samengebracht in een derde metafoor, waarbij leren wordt gezien als een proces waarin kennis wordt gecreëerd; de "knowledge creation" metafoor. Hierbij wordt leren gezien als individuele actieve verwerving van kennis, waaraan betekenis gegeven wordt én als het samen met anderen creëren van nieuwe kennis (Paavola et al., 2004; Paavola \& Hakkarainen, 2005). In deze derde metafoor ligt de nadruk niet uitsluitend op of het individu of de sociale omgeving, maar op de manier waarop lerenden samen nieuwe kennis ontwikkelen. De drie metaforen van leren sluiten elkaar niet uit; ze zijn alle drie nodig om leren beter te begrijpen. Bij het vormgeven van leeromgevingen is het van belang aan te sluiten bij deze uitgangspunten of metaforen over leren aangezien zij ons helpen leren beter te begrijpen en te verklaren. Omdat deze uitgangspunten nogal abstract zijn, zal ik ze in het volgende deel concreter omschrijven aan de hand van vier hedendaagse leerprincipes: constructief leren, zelfgestuurd leren, contextueel leren en samenwerkend leren.

Het eerste leerprincipe is dat leren een actief en constructief proces is waarbij de lerende zelf zijn kennisnetwerk creëert of herstructureert (Chi, 2009). Leren wordt hierbij gezien als een proces van betekenis geven op basis van individuele ervaringen en interacties met anderen. Als we leren willen bevorderen, dan is het van belang dat de lerende zijn voorkennis activeert en nagaat wat hij al weet. Het activeren van voorkennis is van belang omdat het de lerende helpt nieuwe kennis te koppelen aan eerder verworven kennis (Pressly et al., 1992). Daarnaast is leren een constructief proces. Dat wil zeggen dat de lerende nieuwe kennis toevoegt aan en integreert met zijn eerder verworven kennis; bijvoorbeeld door te elaboreren. Door middel van elaboraties legt de 
lerende betekenisvolle nieuwe relaties tussen bestaande kennis en nieuwe informatie. Het principe van elaboreren, de elaboratie-theorie, heeft $u$ vast zelf weleens toegepast. Bijvoorbeeld bij het spelletje 'We gaan op reis en ik neem mee', waarbij deelnemers om de beurt iets toevoegen aan het rijtje, maar eerst moeten herhalen wat de anderen wilden meenemen. Het rijtje is makkelijker te onthouden door betekenisvolle relaties te leggen tussen de genoemde voorwerpen. Dit leggen van betekenisvolle relaties is elaboreren. Door elaboreren ontstaat diepgaand leren, ontdekt de lerende wat hij nog niet weet en wordt kennis geherstructureerd. Uit onderzoek (Chi et al., 2001; Pressly et al., 1992) blijkt dat dit proces het onthouden van informatie op de langere termijn bevordert.

Het tweede leerprincipe is dat de lerende bij voorkeur een actieve rol vervult in het zelf plannen, zelf monitoren en zelf evalueren van zijn leren. Bij zelfgestuurd leren stelt de lerende vast waar zijn leerbehoeftes liggen, vervolgens bepaalt hij zijn doelen, denkt hij na over wat nodig is om die doelen te bereiken, zoals verschillende informatiebronnen, selecteert hij de juiste leerstrategieën en voert die uit en tot slot evalueert hij zowel het proces als het product van het leren (Knowles, 1975). De kern van zelfgestuurd leren is dat de lerende zelf zijn leren plant, volgt en evalueert. In plaats van zelfgestuurd leren wordt ook vaak de term zelfregulerend leren gebruikt. Deze termen vertonen veel overeenkomsten, maar bij zelfgestuurd leren ligt de nadruk sterker op het belang van de leeromgeving, die de lerende de ruimte biedt om zelf leertaken of leermiddelen te kiezen (Loyens et al., 2008). Behalve cognitieve zelfsturing of cognitieve zelfregulatie is motivationele zelfregulatie ook erg belangrijk bij het leren (Boekaerts \& Cascallar, 2006). Hiermee wordt bedoeld dat de lerende zichzelf moet motiveren om aan een taak te beginnen en om daarna inzet te blijven leveren. De lerende wordt geacht zelf zijn motivatie om te leren te sturen of te reguleren om zo zijn doelen te bereiken. De zelfdeterminatie theorie van Ryan en Deci (2000) is een van de belangrijkste hedendaagse motivationele theorieën. Volgens deze theorie heeft de mens behoefte aan een gevoel van autonomie, aan een gevoel van competentie en ook aan verbondenheid met anderen. Uit de zelfdeterminatie theorie volgt dat de leeromgeving bij voorkeur zelfgestuurd leren dient te bevorderen, opdat de lerende zich competent, autonoom en verbonden met anderen kan voelen (Ten Cate et al., 2011). 
Het derde leerprincipe is dat leren bij voorkeur plaatsvindt in een betekenisvolle context. Het verwerven van nieuwe informatie in een professioneel betekenisvolle context bevordert het terugvinden van die informatie. Ik denk dat u dit allemaal zelf weleens aan den lijve hebt ondervonden. $U$ bent bijvoorbeeld aan het winkelen en iemand groet $u$. In eerste instantie groet $u$ vriendelijk terug en vervolgens denkt u: Waar ken ik die persoon toch van? Als de ontmoeting had plaatsgevonden in uw werksituatie, waar u deze persoon normaal gesproken tegenkomt, dan had $u$ hem of haar waarschijnlijk onmiddellijk herkend. In het beroepsonderwijs kan het leren in een betekenisvolle context bevorderd worden door studenten te confronteren met problemen die relevant zijn voor de latere beroepspraktijk. Het is echter niet eenvoudig om te bewerkstelligen dat lerenden dat wat zij in de ene context geleerd hebben kunnen toepassen in een andere context. Transfer van wat geleerd is, ofwel het toepassen van het geleerde in nieuwe situaties, is niet gemakkelijk te verwezenlijken. Om transfer te stimuleren dient de lerende geconfronteerd te worden met meerdere en contrasterende voorbeelden. Hij dient verder aangespoord te worden om te ontdekken welke verschillen en overeenkomsten er zijn tussen situaties, wat de kritische kenmerken zijn van een probleem en welke principes aan bepaalde problemen ten grondslag liggen (Bransford \& Schwartz, 1999). Kortom, om leren te bevorderen moet het bij voorkeur plaatsvinden in een betekenisvolle authentieke context en aan de hand van verschillende problemen.

Het vierde leerprincipe is dat interactief of samenwerkend leren een positief effect heeft op leren doordat lerenden op elkaars kennis voortbouwen waardoor er een gedeeld begrip ontstaat (Chi, 20o9; Dillenbourg, 1999; Van Den Bossche et al., 2011).Vooral het samenwerkend leren in kleine groepen stimuleert wederzijdse interacties tussen lerenden, die aanzetten tot dieper nadenken en beter leren (Johnson et al., 2007; Dolmans \& Schmidt, 2006). Verschillende review studies (Cohen, 1994; Slavin, 1996; Springer et al., 1999; Van der Linden et al., 2000) laten zien dat samenwerkend leren effectiever is dan individueel leren. Dit geldt vooral voor complexe leertaken (Kirschner et al., 2009). Vanuit een cognitief perspectief zet samenwerkend leren aan tot het gezamenlijk (re)construeren van kennis, bijvoorbeeld door vragen te stellen en te beantwoorden, door kennis in eigen woorden te verbaliseren, door voort te bouwen op elkaars argumenten en door te discussiëren over tegenstrijdigheden. Vanuit een sociaal perspectief zorgt het samen leren 
in groepen ervoor dat groepsleden zich ervan bewust worden dat ze elkaar nodig hebben om hun individuele doelen te bereiken en dat alle groepsleden meer kunnen bereiken door samen te werken en elkaar te helpen. Als er een wederzijdse positieve afhankelijkheid bestaat tussen de groepsleden, dan zullen zij elkaars leren helpen en ondersteunen, volgens de sociale wederzijdse afhankelijkheidstheorie ofwel de social interdependence theory (Johnson, Johnson \& Smith, 2007). Vanuit de behoefte aan verbondenheid met anderen zorgen de groepsleden voor elkaar.

Kortom, leeromgevingen moeten vooral aanzetten tot constructief leren, zelfgestuurd leren, contextueel leren en samenwerkend leren. De vraag is echter: Hoe ziet die leeromgeving er dan uit in de praktijk van alledag?

In het volgende deel van mijn betoog zal ik beargumenteren dat probleemgestuurd onderwijs een voorbeeld is van een leeromgeving die goed aansluit op de vier leerprincipes die ik zojuist heb toegelicht. Uiteraard zal ik ook laten zien hoe aan probleemgestuurd onderwijs in de onderwijspraktijk van alledag vorm wordt gegeven.

\section{Deel 2: Probleemgestuurd onderwijs en leerprincipes}

Probleemgestuurd onderwijs is een onderwijsvorm die wereldwijd op grote schaal wordt toegepast, vooral in het hoger onderwijs. Probleemgestuurd onderwijs werd voor het eerst toegepast aan de Universiteit van McMaster in Canada aan het eind van de jaren '70. Barrows, een neuroloog, was een van de belangrijke grondleggers van probleemgestuurd onderwijs. Deze innovatieve onderwijsvorm was destijds een reactie op onvrede met het bestaande onderwijs, waarin veel van wat onderwezen werd irrelevant was voor de latere beroepspraktijk, waarin veel nadruk lag op het overdragen van kennis en waarin weinig aandacht was voor leren redeneren en leren toepassen van wat geleerd was. Allereerst zal ik toelichten hoe een probleemgestuurde onderwijsleeromgeving eruit ziet en hoe ik probleemgestuurd onderwijs definieer. Er bestaan immers vele varianten van probleemgestuurd onderwijs.

In probleemgestuurd onderwijs werken studenten samen in kleine groepen van ongeveer 10 studenten aan problemen of leertaken onder 
begeleiding van een docent. De studenten bespreken de problemen of leertaken, die vaak gerelateerd zijn aan de uiteindelijke professionele beroepscontext. Hierbij activeren ze in eerste instantie hun voorkennis. Tijdens deze discussie ontdekken de studenten wat ze nog niet goed genoeg beheersen en nadere zelfstudie vereist. Deze discussie, de voorbespreking, resulteert dan ook in het formuleren van leerdoelen die nader bestudeerd moeten worden. Hierna volgt een fase van zelfstudie, waarin studenten de leerdoelen gaan bestuderen met gebruikmaking van allerlei bronnen. Na deze zelfstudie, die meestal een periode van twee dagen beslaat, komen de studenten weer bijeen om met elkaar te discussiëren over het probleem of de leertaak. Ze rapporteren aan elkaar wat ze geleerd hebben over de leerdoelen, maar bespreken ook onduidelijkheden in de leerstof en proberen het geleerde toe te passen op het probleem of de leertaak. De docent vervult tijdens de discussie een faciliterende rol door af en toe vragen te stellen om de lerenden aan te zetten tot dieper nadenken, tot toepassen van het geleerde en tot evalueren. Essentiële kenmerken van probleemgestuurd onderwijs zijn: 1) het leren vindt plaats in kleine groepen, 2) de docent faciliteert het leren in de groep, 3) het leren vindt plaats aan de hand van problemen of leertaken die eerst besproken en vervolgens bestudeerd worden en 4) de lerende verwerft nieuwe kennis door zelfstudie gevolgd door discussie in de groep (Barrows \& Tamblyn, 1980). De problemen of leertaken en de onderwijsgroep vormen dus de belangrijkste drijfveren voor het leren in een probleemgestuurd onderwijsprogramma en niet de lezingen zoals veelal het geval is in een docentgestuurd of traditioneel onderwijsprogramma.

In probleemgestuurd onderwijs wordt dus geleerd aan de hand van problemen of leertaken. Die leertaken zetten aan tot het activeren van voorkennis, tot nadenken over wat de lerende al weet en wat hij nog niet weet. Door de discussie in de groep wordt de lerende er ook toe aangezet om te elaboreren, om nieuwe informatie te koppelen aan al bekende informatie. De lerende wordt dus aangezet tot constructieve kennisverwerving. Ten tweede formuleert de lerende leerdoelen die nadere zelfstudie vereisen en wordt hij ertoe aangezet zelf bronnen te zoeken. De lerende wordt dus ook aangezet tot zelfgestuurd leren. De discussie heeft bovendien een motiverende werking, omdat deze de interesse in de leerstof vergroot. Ten derde zijn de problemen of leertaken die bediscussieerd worden vaak afgeleid van problemen die relevant zijn voor de latere beroepspraktijk. Daarmee wordt het 
contextuele leren bevorderd. Ten vierde vindt het leren plaats in een groep waardoor de lerende wordt aangezet tot diepgaande interacties die het leren bevorderen evenals de verbondenheid met anderen. Kortom, probleemgestuurd onderwijs sluit aan bij de eerder geschetste hedendaagse principes over leren (Dolmans et al., 2005).

Maar, de vraag is uiteraard: Wat is er bekend uit onderzoek op het gebied van probleemgestuurd onderwijs? Is er empirisch bewijs voor het voorgaande betoog? In het volgende deel van mijn betoog ga ik in op wat er bekend is uit onderzoek op het gebied van probleemgestuurd onderwijs.

\section{Deel 3: Onderzoek op het gebied van probleemgestuurd onderwijs}

$\mathrm{Er}$ is de afgelopen jaren veel onderzoek gedaan op het gebied van probleemgestuurd onderwijs, vooral binnen het domein van de opleidingen in de geneeskunde en de gezondheidswetenschappen. Het onderzoek dat ik hieronder beschrijf betreft dan ook veelal onderzoek dat binnen deze context verricht is.

De eerste studies naar probleemgestuurd onderwijs waren vooral beschrijvend. Beschreven werd hoe vorm gegeven werd aan probleemgestuurd onderwijs en wat de percepties van studenten en docenten waren over het onderwijs. In 1993 verschenen de eerste reviews over probleemgestuurd onderwijs van Albanese en Mitchell (1993) en van Vernon en Blake (1993). In beide reviews werd geconcludeerd dat probleemgestuurd onderwijs in vergelijking met traditioneel onderwijs een plezierige manier van leren en onderwijzen is. In 2000 verscheen een kritisch review van Colliver (2000), waarin geconcludeerd werd dat er geen overtuigend bewijs bestond dat probleemgestuurd onderwijs leidt tot het verbeteren van kennis en dat de relatie tussen de theorie die ten grondslag ligt aan probleemgestuurd onderwijs en het onderzoek erg los is.

In 2003 verscheen een interessante review van Dochy et al. (2003). Hierin werden studies op een rij gezet waarin de effecten van probleemgestuurd onderwijs op leerprestaties werden gemeten. Er werd gekeken naar de effecten op kennistoetsen, veelal bestaand uit meerkeuzevragen, waarmee kennis van feiten en de betekenis van concepten en principes 
getoetst worden, en naar de effecten op toetsen die het toepassen van kennis meten, zoals open vragen of casus of problemen die opgelost moeten worden. Probleemgestuurd onderwijs zou immers vooral moeten leiden tot het leggen van relaties tussen begrippen en het kunnen toepassen van wat men geleerd heeft. Uit deze review blijkt dat er wat betreft het verwerven van kennis sprake is van een licht negatief, maar niet significant effect. Wat betreft het toepassen van kennis blijkt probleemgestuurd onderwijs tot een duidelijk positief effect te leiden. Hoe meer de toets toepassing van kennis meet, des te groter is het positieve effect van probleemgestuurd onderwijs.

In 2005 verschijnt er echter een andere interessante review van Gijbels et al. (2005), waarin op een meer verfijnde manier gekeken wordt naar de effecten van probleemgestuurd onderwijs. Nagegaan is of probleemgestuurd onderwijs positieve effecten heeft op:1) het begrijpen van concepten, 2) het begrijpen van principes waarmee concepten aan elkaar gerelateerd zijn en 3) het toepassen van principes en procedures. Juist-onjuistvragen of meerkeuzevragen werden beschouwd als toetsen die het begrijpen van concepten meten. Toetsen waarin problemen opgelost moeten worden werden veelal gecodeerd als toetsen die relaties tussen concepten meten. En toetsen die bestaan uit simulaties of die prestaties in de echte praktijk meten, werden beschouwd als toetsen die toepassing meten. Uit deze review (Gijbels et al., 2005) blijkt dat probleemgestuurde curricula in vergelijking met traditionele curricula een sterk positief effect hebben op het leggen van relaties tussen concepten. Voor wat betreft het toepassen van kennis, zoals gemeten met simulaties of praktijkbeoordelingen, werd er eveneens een positief maar niet significant effect gevonden. Overigens werd de toepassing van kennis in slechts een beperkt aantal studies gemeten. Ten aanzien van het begrijpen van concepten werd geen verschil gevonden. In het algemeen kan op basis van de reviews die ik tot nu toe besproken heb, geconcludeerd worden dat er geen verschillen worden gevonden tussen probleemgestuurde en traditionele curricula wat betreft het verwerven van kennis van concepten, al is er wel een positief effect op het leggen van relaties tussen concepten (zie ook Walker \& Leary, 2009).

De tegenvallende bevindingen op het gebied van kennis hebben tot felle discussies geleid. Kirschner et al. (2006) verklaren de tegenvallende resultaten van constructivistische leeromgevingen door erop te wijzen dat leeromgevingen waarbij sprake is van minimale sturing door de 
docent, waaronder probleemgestuurd onderwijs, een te grote cognitieve belasting voor het werkgeheugen van de lerende met zich meebrengen. Maar, is er bij probleemgestuurd onderwijs wel sprake van minimale sturing door de docent? Eerder beschreef ik de essentiële kenmerken van probleemgestuurd onderwijs, waaronder de aanwezigheid van een docent die het leren faciliteert en het leren aan de hand van problemen of leertaken. In probleemgestuurd leren dat aan deze kenmerken voldoet, is er wel degelijk sprake van ondersteuning van de lerende om de cognitieve belasting voor het geheugen te reduceren. $\mathrm{Er}$ is een docent die kritische vragen stelt tijdens de discussie. Er is sprake van problemen of leertaken die zorgvuldig ontworpen worden om te zorgen dat ze goed aansluiten op de voorkennis van de student en goed op elkaar voortbouwen. De opvatting dat de leeromgeving moet aanzetten tot zelfgestuurd leren wordt nog maar al te vaak door sommigen geassocieerd met het geven van minimale sturing door de docent. Binnen probleemgestuurd onderwijs vindt er sturing plaats door de docent terwijl de lerende tegelijkertijd aangezet wordt tot zelfgestuurd leren, bijvoorbeeld door het zelf formuleren van leerdoelen die nadere studie vereisen. Zowel onderwijskundigen als neurowetenschappers zijn het erover eens dat lerenden sturing door een docent nodig hebben om te kunnen leren. Dit betekent dat er in het begin veel docentsturing gegeven moet worden bij het leren van nieuwe problemen of leertaken en dat deze sturing vervolgens geleidelijk moet worden afgebouwd. Probleemgestuurd onderwijs is een instructievorm waarin wel ondersteuning wordt geboden aan de lerende, maar waarin de lerende tegelijkertijd aangezet wordt tot zelfgestuurd leren.

De bevinding uit de reviews dat lerenden in probleemgestuurd onderwijs wat betreft het verwerven van kennis in het algemeen niet beter, maar ook niet slechter presteren (Prince et al., 2005), geeft nog steeds aanleiding tot verder onderzoek. Uit een studie van Schmidt et al. (2009), waarin probleemgestuurde en traditionele curricula in Nederland vergeleken worden, blijkt dat probleemgestuurde curricula gekenmerkt worden door een hoger percentage geslaagden en een kortere studieduur. Dit zou kunnen betekenen dat in probleemgestuurde curricula ook de zwakkere studenten de opleiding afmaken. Indien in de probleemgestuurde curricula de 11 procent zwakst scorende studenten de studie niet zouden afmaken, ofwel indien gecorrigeerd wordt voor een lagere studie-uitval conform de docentgecentreerde curricula, dan blijken probleemgestuurde curricula gemiddeld wel tot 
betere studieprestaties te leiden, aldus een recent artikel van Schmidt et al. (2012). Opgemerkt moet hierbij worden dat, hoewel de studenten van deze curricula wat betreft vooropleiding goed vergelijkbaar zijn en op vergelijkbare toetsresultaten, zijnde voortgangstoetsresultaten, met elkaar vergeleken worden, het toch moeilijk is om verschillende curricula met elkaar te vergelijken. Probleemgestuurde en traditionele curricula verschillen immers niet alleen in termen van studierendement en studieduur, maar ook in examenreglementen en de mate waarin deze uitstelgedrag van studenten voorkómen en in de tijd die is ingeruimd voor zelfstudie. Het bevorderen van regelmatige zelfstudie en het voorkómen dat lerenden uitstelgedrag vertonen ten aanzien van het studeren zijn ook cruciale elementen van het succes van probleemgestuurde curricula (Schmidt et al., 2010a; Schmidt et al., 2010b).

Overigens is er niet alleen onderzoek gedaan waarin curricula vergeleken worden metals doelverschillen tussen probleemgestuurde en traditionele curricula op te sporen. Capon en Kuhn (2004) deden experimenteel onderzoek in een natuurlijke setting waarin probleemgestuurde discussie vergeleken werd met het geven van een lezing met discussie. De resultaten van deze studie, gemeten twaalf weken na afloop van het onderwijs door middel van twee open vragen over een korte casus, laten zien dat de deelnemers uit de probleemgestuurde conditie betere uitleg gaven over het concept dat bediscussieerd was. Een mogelijke verklaring voor deze bevinding is dat de nieuw verworven kennis door middel van de discussie in de probleemgestuurde conditie beter geïntegreerd werd met de reeds eerder verworven kennis. Recent is een vergelijkbaar onderzoek gedaan waarin probleemgestuurd onderwijs en het geven van een lezing met discussie vergeleken werden in een natuurlijke setting bij elfjarige leerlingen. Ook uit deze studie, waarin de deelnemende leerlingen negen weken na het onderwijs het geleerde moesten toepassen bij het beantwoorden van open vragen, blijkt dat de leerlingen in de probleemgestuurde condities beter presteerden dan de leerlingen die een lezing met discussie gevolgd hadden (Wirkala \& Kuhn, 2011).

Tot nu toe heb ik studies gerapporteerd waarin vooral onderzocht is of er verschillen zijn in studieprestaties tussen probleemgestuurde en traditionele curricula. Maar, zijn er misschien nog andere voordelen van probleemgestuurd onderwijs? Leidt probleemgestuurd onderwijs tot het verwerven van vaardigheden voor levenslang leren? Aangezien 
studenten in probleemgestuurd onderwijs in kleine groepen met elkaar samenwerken aan leertaken of problemen die relevant zijn voor de latere beroepsuitoefening en aangezet worden tot zelfgestuurd leren, zou probleemgestuurd onderwijs ook het verwerven van vaardigheden voor levenslang leren moeten bevorderen. Het betreft vaardigheden zoals communiceren, samenwerken, bijeenkomsten leiden en om kunnen gaan met kritiek en onzekerheden. Ook hier is veel onderzoek naar gedaan, waarbij meestal aan afgestudeerden gevraagd wordt in welke mate zij zichzelf competent vinden op een lijst van vaardigheden en in welke mate de genoten opleiding daaraan heeft bijgedragen. Het betreft studies waarin afgestudeerden van probleemgestuurde curricula vergeleken worden met afgestudeerden van traditionele curricula. Hieruit blijkt dat afgestudeerden van probleemgestuurde curricula zichzelf positiever beoordelen op communiceren, samenwerken en omgaan met onzekerheden. Er zijn vele studies gedaan waarin deze bevindingen systematisch gerapporteerd worden (Cohen-Schotanus et al., 2008; Hmelo-Silver, 2004; Hoffman et al., 2006; Jones et al., 2002; Meng \& Heijker, 2005; Prince et al., 2005; Schlett et al, 2010; Schmidt \& van der Molen, 2001; Schmidt et al., 2006; Schmidt et al., 2010b). Er is overigens ook bewijs dat het verwerven van deze generieke competenties niet koste gaat van het verwerven van domeinspecifieke competenties (Meng \& Heijke, 2005). De resultaten van de vele onderzoeken waarin de percepties van afgestudeerden zijn onderzocht, worden bevestigd door supervisoren van afgestudeerden, ofwel door observaties door anderen, die eveneens in enkele studies zijn bevraagd (Jones et al., 2002, Hoffman et al, 2006). Maar, voor al deze studies geldt dat het vergelijken van curricula niet eenvoudig is, en wel om twee redenen. Ten eerste omdat het in het onderwijs onmogelijk is interventies blind uit te voeren. Uit onderzoek van Loyens et al. (2006) blijkt immers dat de opvattingen over leren van studenten in probleemgestuurde en traditionele curricula reeds bij de start van de opleiding van elkaar verschillen. De studenten die gekozen hebben voor probleemgestuurd onderwijs hechten meer belang aan samenwerkend leren dan de studenten die kozen voor een traditioneel curriculum. Ten tweede omdat probleemgestuurde curricula onderling ook van elkaar verschillen en niet volledig vergelijkbaar zijn (Norman \& Schmidt, 2000).

Veel interessanter dan de vraag of probleemgestuurd onderwijs leidt tot betere studieprestaties is de vraag waarom en onder welke condities probleemgestuurd onderwijs effectief is. In het begin betoogde ik dat probleemgestuurd onderwijs gebaseerd is op vier hedendaagse 
principes over leren. Deze leerprincipes en hun onderliggende theorieën vormen de theoretische basis van probleemgestuurd onderwijs en zouden dan ook veel meer de leidende ingrediënten moeten zijn voor onderzoek. Dit zou betekenen dat in studies vragen centraal staan als: Hoe percipiëren lerenden de probleemgestuurde leeromgeving? Zet de leeromgeving aan tot actief of constructief, zelfgestuurd, contextueel en samenwerkend leren?

In 2006 heb ik een aantal bevindingen uit 37 studies in een review op een rij gezet en gekeken naar de onderliggende leerprincipes in probleemgestuurd onderwijs. In een review uit 2011 (Schmidt et al., 2011) is eveneens een aantal studies op een rij gezet waarin leerprincipes van probleemgestuurd onderwijs onderzocht zijn evenals studies naar de condities waarin probleemgestuurd onderwijs werkt. Ter illustratie beschijf ik hieronder enkele van deze studies. Er zijn studies gedaan die laten zien dat activerend en constructief leren in probleemgestuurd onderwijs leidt tot meer diepgaand leren en meer zelfgestuurd leren (Dolmans et al., 2010; Hofgaard Lycke et al., 2006; Van der Veken et al., 2008). Een interessant voorbeeld van onderzoek naar het principe van constructief leren betreft een studie van Van Blankenstein et al. (2011), waarin het effect van elaboreren is onderzocht in een gesimuleerde onderwijsgroep onder gecontroleerde condities. In deze studie werd nagegaan of luisteren naar de discussie versus actief elaboreren een verschillend effect had op het onthouden van informatie op de korte en lange termijn. Uit deze studie bleek dat de lerenden die elaboreerden beduidend meer onthielden op zowel korte als lange termijn dan de luisteraars. Elaboraties in probleemgestuurd onderwijs leiden dus tot beter leren. Uit onderzoek van Van den Hurk et al. (2006) naar zelfgestuurd leren blijkt dat naarmate lerenden in probleemgestuurd onderwijs in hun studie vorderen, zij zich bij hun zelfstudie meer laten leiden door hun eigen leerdoelen en interesses en ook dat zij beter presteren, naarmate ze meer om de leerdoelen heen studeren. Uit een andere recente interessante studie op het gebied van zelfgestuurd leren blijkt dat discussie in de onderwijsgroep een positief effect heeft op de situationele interesse van de lerende in de leerstof, en dat deze interesse bovendien positief gerelateerd is aan de studieprestaties (Rotgans \& Schmidt, 2011). Op het gebied van contextueel leren blijkt dat discussiëren naar aanleiding van echte patiëntproblemen in plaats van papieren leertaken enorm motiverend is voor studenten en aanzet tot zowel analytisch als niet-analytisch redeneren (Diemers et al., 
2008). Onderzoek op het gebied van samenwerkend leren waarbij groepen geobserveerd zijn in probleemgestuurd onderwijs heeft aangetoond dat de onderwijsgroep vooral aanzet tot redeneringen die op elkaar voortbouwen, tot het stellen van exploratieve vragen en tot het bediscussiëren van tegenstrijdigheden in de leerstof (VisschersPleijers, 2006), hoewel met name het bespreken van tegenstrijdigheden verbetering behoeft (Aarnio et al., 2012). Dit soort studies geeft ons beter inzicht in de werkzame ingrediënten van probleemgestuurd onderwijs.

Erisookonderzoekgedaan naardeconditieswaaronder probleemgestuurd onderwijs effectief is. Een mooi voorbeeld hiervan betreft onderzoek naar de docent in probleemgestuurd onderwijs. De docent, die tutor genoemd wordt in probleemgestuurd onderwijs, vervult een andere rol dan de docent in traditionele curricula; de tutor moet immers vragen stellen die aanzetten tot dieper nadenken, het proces in de groep bewaken en zorgen dat alle groepsleden actief participeren. Met betrekking tot het functioneren van de tutor is er dan ook veel onderzoek gedaan naar de vraag of een tutor inhoudsdeskundig moet zijn of vooral goed het proces moet kunnen leiden. Hierbij werd in het begin vooral gekeken welke tutorkenmerken resulteerden in betere toetsprestaties. Dit onderzoek leverde tegenstrijdige resultaten op. In latere studies werd gekeken naar de interactie tussen het gedrag van de tutor in relatie tot andere variabelen, bijvoorbeeld de problemen of de leertaken. Uit dit onderzoek blijkt dat de inhoudsdeskundigheid van de tutor van groter belang is als de problemen of leertaken onvoldoende sturing bieden voor de studenten. Als de problemen of leertaken voldoende sturende elementen bevatten, is er uiteraard minder inhoudelijke sturing door de docent vereist. Overigens blijkt uit onderzoek dat een goede tutor beschikt over zowel enige inhoudsdeskundigheid als over vaardigheden om de onderwijsgroep goed te begeleiden. Een overzicht van het onderzoek op het gebied van de tutor is op een rij gezet in een review van Dolmans et al. (2002).

Zoals ik eerder beschreef, betreft het voornamelijk onderzoek dat gedaan is binnen geneeskundige of gezondheidswetenschappelijke probleemgestuurde curricula. Het is dan ook de vraag in hoeverre deze bevindingen gegeneraliseerd kunnen worden naar andere domeinen. $\mathrm{Er}$ wordt bijvoorbeeld onderzoek gedaan naar probleemgestuurd onderwijs in statistiek, een onderwerp dat voor studenten in veel universitaire studies een van de grote struikelblokken is. Hieruit blijkt dat sommige 
studenten minder voorkennis over statistiek hebben, waardoor het nodig is meer docentsturing in te bouwen (Budé et al., 2009; Leppink, 2012). Maar, er is meer onderzoek nodig naar probleemgestuurd onderwijs en de vraag in welke condities het effectief is binnen verschillende domeinen.

\section{Deel 4: Problemen in de praktijk en innovatieve oplossingen}

Leidt innoveren van onderwijs tot beter leren? Leidt probleemgestuurd onderwijs tot beter leren? Niet alle onderwijsinnovaties leiden in alle omstandigheden tot beter leren. Helaas is er geen recept te geven voor een onderwijsvorm die altijd en onder alle condities effectief is. Leren is een complex proces waarin allerlei factoren elkaar beïnvloeden, zoals ook Berliner (2002) beweert in zijn artikel "Educational research: The hardest science of all". Niet alleen kenmerken van de lerende, zoals de mate van zelfsturing van het leren, doorzettingsvermogen en motivatie, maar ook vele kenmerken van de leeromgeving, zoals de mate waarin er interacties plaatsvinden tussen lerenden en docenten en de hoeveelheid tijd die besteed wordt aan taken, zelfstudie en andere leeractiviteiten, beïnvloeden allemaal de effectiviteit van het onderwijs. Met andere woorden, het is moeilijk om in onderwijsonderzoek uitspraken te doen die altijd en onder alle omstandigheden geldig zijn. Docenten die werkzaam zijn in de onderwijspraktijk zullen zelf ook aan den lijve hebben ervaren dat flexibiliteit van handelen cruciaal is en aangepast moet zijn aan hoe lerenden in een bepaalde situatie reageren.

Probleemgestuurd onderwijs is eveneens niet onder alle omstandigheden effectief. Door mijn collega Moust et al. (2005) is beschreven dat probleemgestuurd onderwijs ook aan slijtage onderhevig is. Maar, welke problemen worden er dan in de praktijk ervaren? Een van de problemen betreft onderwijsgroepen die gekenmerkt worden door oppervlakkige in plaats van diepgaande discussies. De groepsdiscussie is een soort rituele dans geworden (Dolmans et al., 2001), waardoor de cognitieve voordelen, zoals het activeren van voorkennis en diepgaande elaboraties, nauwelijks plaatsvinden. Er is weinig sprake van het delen van kennis en het samen construeren van kennis. Ook worden tegenstrijdigheden in de leerstof onvoldoende besproken. Een ander probleem betreft een gebrek aan betrokkenheid van sommige groepsleden bij de groep, waardoor sommige groepsleden weinig moeite doen om deel te nemen aan de 
discussie en anderen het werk laten doen, wat leidt tot een negatieve in plaats van een positieve wederzijdse afhankelijkheid. Een derde probleem betreft een gebrek aan interesse of slechte voorbereiding door sommige groepsleden, waardoor de deelname van de betreffende groepsleden gering is. Kortom, problemen liggen op het cognitieve vlak, zoals een oppervlakkige discussie, op het sociale vlak, zoals een gebrek aan positieve wederzijdse afhankelijkheid, en op het motivationele vlak, zoals gebrek aan interesse of motivatie om zich goed voor te bereiden.

Een mogelijke oorzaak van het probleem van een oppervlakkige discussie ligt op het vlak van de problemen of leertaken. Te sterk gestructureerde of te eenvoudige problemen of leertaken dagen de lerenden niet uit tot interacties en kunnen beter individueel bestudeerd worden. Leertaken die niet goed geordend zijn van eenvoudig naar complex kunnen eveneens een oorzaak zijn. De afgelopen jaren zijn er binnen het geneeskundeonderwijs naast papieren problemen of leertaken ook elektronische virtuele patiënten, video's van echte patiëntproblemen (De Leng et al., 2007) en echte patiënten geïntroduceerd in probleemgestuurd onderwijs. Uit onderzoek van Diemers et al. (2008) blijkt dat het leren aan de hand van contacten met echte patiënten, zoals dat plaatsvindt in het derde jaar van de opleiding geneeskunde aan deze instelling, door studenten als enorm motiverend worden ervaren. Ook blijkt uit dit onderzoek (Diemers et al., 2011) dat de leertaken aanzetten tot het verwerven van zowel klinische als biomedische kennis die van belang is voor het stellen van de juiste diagnose.

Een mogelijke oorzaak van het probleem van gebrek aan positieve wederzijdse afhankelijkheid in de groep is dat er sprake is van te weinig cohesie in de groep; er is geen teamgeest. Een mogelijke oplossing om de positieve sociale afhankelijkheid tussen groepsleden te bevorderen is peer feedback. Peer feedback betekent dat groepsleden elkaar feedback geven en van elkaar feedback krijgen, bijvoorbeeld op hun bijdragen aan de groepsdiscussies. Uit onderzoek van Kamp et al. (2012) is gebleken dat peer feedback in probleemgestuurd onderwijs over de bijdrage van elk groepslid aan de groepsdiscussie de groepsleden bewust maakt van het gewenste gedrag in de onderwijsgroep en ook het gevoel van betrokkenheid bevordert. Dit betekent dat peer feedback groepsleden ertoe kan aanzetten elkaar te ondersteunen, doordat ze zich ervan bewust worden dat ze door samen te werken ook individueel meer 
kunnen leren. Een mogelijke oorzaak van motivationele problemen van een individuele lerende die zich onvoldoende voorbereidt, is dat de sturing die de docent biedt in de onderwijsgroep niet aansluit bij de mate waarin de lerende zelf zijn leren kan sturen. Dit kan zich voordoen als de docent te sturend de groep leidt en een minilezing geeft of juist te weinig sturing biedt. Om de lerende te motiveren zich goed voor te bereiden op de discussie in de onderwijsgroep kan de groep gesplitst worden in kleine subgroepen of teams die onderdelen van de leerstof samen voorbereiden en aan elkaar presenteren in de groep. Ook hier is ervaring mee opgedaan. Uit onderzoek blijkt dat lerenden het werken in subgroepen een prettige manier van samenwerken vinden en dat dit bovendien leidt tot een toename van de tijd die besteed wordt aan zelfstudie (Roebertsen et al., 2004). Het is hierbij wel van belang dat de subgroepen met elkaar discussiëren over de leerstof. Voorkomen moet worden dat de lerenden minilezingen gaan geven aan elkaar zonder dat er sprake is van diepgaande interacties tussen de groepsleden over de leerstof.

Onderwijsinnovaties worden aan de Universiteit Maastricht gestimuleerd door middel van het programma "Leading in Learning". In dit kader zijn er vele projecten opgestart binnen deze instelling om het onderwijs te innoveren. Ik denk daarbij aan projecten waarbij lerenden met elkaar discussiëren op afstand via allerlei elektronische tools, zoals Elluminate en blogs, maar ook aan het gebruik van smartboards, concept-mapping software, de iPhone, facebook en elektronische trainingsprogramma's voor docenten. Deze innovaties zijn niet altijd gericht op het aanzetten tot beter leren, maar bijvoorbeeld bedoeld om probleemgestuurd leren op afstand mogelijk te maken. Aan deze projecten wordt vaak onderzoek gekoppeld. In een recent gepubliceerde kleinschalige studie werd bijvoorbeeld een online asynchrone discussie in een probleemgestuurd onderwijsprogramma met afstandsonderwijs vergeleken met een faceto-face discussie over een moeilijk onderwerp, in dit geval statistiek. Uit deze studie bleek dat studenten zeer tevreden waren over de online variant en dat de studieprestaties niet significant verschilden (De Jong et al., 2012). De koppeling met onderzoek kan echter verder versterkt worden door docenten, onderwijsontwikkelaars en onderzoekers nog meer met elkaar te laten samenwerken bij het onderzoeken van onderwijsinnovaties. 


\section{Deel 5: Onderzoeksagenda}

Het onderzoek op het gebied van probleemgestuurd onderwijs heeft de afgelopen jaren een enorme ontwikkeling doorgemaakt, zoals ik eerder uiteen heb gezet. Daarbij heb ik betoogd dat onderwijs en leren enorm complex zijn. In het onderwijs vindt wederzijdse beïnvloeding plaats tussen vele kenmerken van de leeromgeving, de studenten en de docenten. In plaats van alleen te kijken naar de uitkomsten van onderwijs en curricula te vergelijken zou er meer verklarend onderzoek gedaan moeten worden (Cook et al., 2008). Studies gericht op het beter begrijpen en verklaren van de complexe processen in onderwijs en leren, waarin vele aspecten met elkaar interacteren (Regehr, 2010). Studies waarin vragen centraal staan zoals: Waarom en onder welke condities is probleemgestuurd onderwijs effectief? In het begin betoogde ik dat probleemgestuurd onderwijs gebaseerd is op vier hedendaagse principes over leren. Deze leerprincipes en hun onderliggende theorieën vormen de theoretische basis en zouden dan ook veel meer de leidende ingrediënten moeten zijn voor onderzoek naar probleemgestuurd onderwijs. Studies waarin meer gebruik gemaakt wordt van kwalitatieve methoden. Maar ook meer design-based onderzoek, studies waarbij vanuit theorieën of leerprincipes de leeromgeving herontworpen of verbeterd en onderzocht wordt. Hierbij verbeteren onderzoekers samen met onderwijsontwikkelaars, docenten en lerenden de leeromgeving, onderzoeken deze en leveren op deze wijze een bijdrage aan zowel het testen en verfijnen van theorieën als het verbeteren van de onderwijspraktijk. Onderzoek dus waarbij sprake is van een nauwe koppeling tussen theorie en praktijk en waarmee bruggen gebouwd kunnen worden tussen onderwijsonderzoek en de onderwijspraktijk (Anderson \& Shattuck, 2012; Dolmans \& Tigelaar, 2012).

Mijn toekomstig onderzoek richt zich op drie cruciale aspecten van de leeromgeving: 1) de problemen of leertaken, 2) de groep en 3) de docenten. De leerprincipes die ik eerder beschreef zijn leidend. In het onderzoek rondom het eerste aspect, de problemen of leertaken, staat vooral het principe van leren in een betekenisvolle context centraal. In dit onderzoek wordt leren aan de hand van virtuele en echte patiëntproblemen onderzocht. Zetten deze betekenisvolle leertaken aan tot leren klinisch redeneren en treedt er transfer op van het geleerde naar andere leertaken die niet aan de orde zijn geweest maar wat betreft onderliggende mechanismen vergelijkbare kennis 
vergen? Onderzoek naar de mate waarin probleemgestuurd onderwijs transfer van het geleerde bevordert is schaars. In onderzoek rondom het tweede aspect van de leeromgeving, de groep, staan de principes van samenwerkend leren en zelfgestuurd leren centraal. In onderzoek van singaram et al. (2011) naar probleemgestuurd onderwijs in een setting waarin sprake is van enorme verschillen tussen studenten wat betreft hun culturele achtergrond en de beheersing van de taal die in de groep gesproken wordt, blijkt dat het samenwerkend leren in de groep naast veel voordelen, studenten kunnen veel van elkaar leren, ook spanningen met zich meebrengt en voor sommige studenten demotiverend werkt. In onderzoek dat momenteel wordt uitgevoerd gaan we na of peer feedback, het geven en ontvangen van feedback van en door groepsleden, een bijdrage levert aan het verbeteren van de discussie en het samen leren in de groep. Bij het derde aspect van de leeromgeving, de docent, staat vooral het principe van constructief en zelfgestuurd leren centraal. Hierbij wordt onderzoek gedaan naar de vraag hoe het leren van de docent bevorderd kan worden en hoe de docent de lerende kan aanzetten tot constructief en zelfgestuurd leren. Wat zijn kenmerken van effectieve docentprofessionaliseringsprogramma's (Steinert et al., 2006)? Er wordt een hernieuwde review op dit gebied voorbereid door Yvonne Steinert waaraan ik een bijdrage lever. Ook wordt er onderzoek gedaan naar het effect van het trainen van artsen in het geven van feedback aan artsen-in-opleiding over de manier waarop ze effectief kunnen communiceren met patiënten. Daarnaast betreft het onderzoek waarin nagegaan wordt hoe de sturing door de docent verminderd en de zelfsturing door de lerende vergroot kan worden door het gebruik van elektronische ontwikkelingsportfolio's met elektronische coachingsprotocollen in het Middelbaar Beroeps Onderwijs. Het doel is om leerlingen aan te zetten tot zelfgestuurd leren door ze te leren zelf prestaties op leertaken te beoordelen, zelf na te gaan wat goed ging en wat verbeterd moet worden en op basis daarvan zelf vervolgens nieuwe leertaken te selecteren. Leerlingen blijken daartoe in staat mits ze goed begeleid worden door de docent. In het onderzoek wordt nagegaan of het mogelijk is de docenttijd daarbij te beperken. Tot slot hoop ik onderzoek naar de rol van de docent bij interne kwaliteitszorgactiviteiten te kunnen voortzetten. Uit een promotieonderzoek dat recent is afgerond blijkt dat het continu verbeteren van de kwaliteit van onderwijs door docenten in de dagelijkse onderwijspraktijk een kwaliteitscultuur vereist waarin sprake is van nauwe samenwerking tussen docenten en veel formele en informele communicatie (Kleijnen et al., 2012). 
Bij het uitvoeren van deze onderzoeksagenda wil ik graag ook de mensen uit de onderwijspraktijk betrekken, omdat zij een belangrijke inspiratiebron zijn voor het onderzoek. Vele docenten en artsen in onze onderzoeksgroep zijn zeer betrokken bij het analyseren en innoveren van hun onderwijspraktijk en leveren daarmee een belangrijke bijdrage aan de verbetering van de onderwijspraktijk en het beter begrijpen van leren.

Tot slot, in het strategisch programma van de Universiteit Maastricht voor de periode 2012-2016 wordt opgemerkt dat probleemgestuurd onderwijs een onderscheidend kenmerk blijft van alle opleidingen die aan deze instelling worden aangeboden. Ook wordt opgemerkt dat het een ambitie van deze instelling is om het onderwijs continu te blijven innoveren, onder andere door middel van het Leading in Learning programma. Leren en innoveren zal een van de centrale ambities van de Universiteit Maastricht zijn. Ook het Maastricht UMC+ ziet de kwaliteit van het onderwijs als een speerpunt. Hierbij wordt met name het belang van een leven lang leren benadrukt, waarin naast domeinspecifieke kennis ook generieke competenties van belang zijn, zoals goed kunnen samenwerken en communiceren. Probleemgestuurd onderwijs past prima bij dit speerpunt zoals ik in het voorgaande heb betoogd. Het onderzoeksprogramma van mij en de groep waarin ik werk wil graag een bijdrage leveren aan het realiseren van de ambities van deze instelling ten aanzien van een levenlang leren en innoveren.

\section{Deel 6: Conclusie}

Ik heb betoogd dat probleemgestuurd onderwijs nauw aansluit bij hedendaagse principes over leren. Ik heb betoogd dat probleemgestuurd onderwijs voor lerenden en docenten een plezierige manier van leren is, dat in veel studies gerapporteerd wordt dat probleemgestuurd onderwijs tot vergelijkbare toetsprestaties leidt als docent-gecentreerde curricula en dat probleemgestuurd onderwijs een positief effect heeft op het leggen van relaties tussen concepten. Ook heb ik betoogd dat probleemgestuurd onderwijs positieve effecten heeft op communiceren, samenwerken en omgaan met onzekerheden. Maar, probleemgestuurd onderwijs is niet altijd effectief. In de praktijk worden eveneens problemen ervaren, die vragen om onderwijsinnovatie, waaraan vele docenten in deze instelling een bijdrage leveren. Maar innovaties zijn eveneens nodig omdat de maatschappij verandert, lerenden 
veranderen, er communicatie-technologisch allerlei ontwikkelingen zijn, sociale media beschikbaar zijn en professies veranderen. Al deze veranderingen maken het eveneens noodzakelijk om probleemgestuurd onderwijs voortdurend te blijven innoveren. $\mathrm{Er}$ is onderzoek nodig naar velerlei innovatieve toepassingen in probleemgestuurd onderwijs. Onderzoek waarin er samen met docenten naar gestreefd wordt om probleemgestuurd onderwijs, dat zeer complex is, beter te begrijpen en te verklaren. Onderzoek waarin nagegaan wordt onder welke condities innoveren leidt tot beter leren. Ik hoop daar de komende jaren een bijdrage aan te kunnen leveren. 


\section{Dankwoord}

Tot slot wil ik nog enkele woorden van dank uitspreken.

Ten eerste dank aan het College van Bestuur van de Universiteit Maastricht, de rector Magnificus, de Raad van Bestuur van het MUMC+ en de Decaan van de FHML voor het in mij gestelde vertrouwen.

Ik werk al vele jaren met veel plezier aan de Universiteit Maastricht. Ik heb daar met heel veel mensen de afgelopen jaren samen gewerkt. Ik had hier vandaag niet gestaan als al die mensen mij geen kansen hadden gegeven van hen te mogen leren. Ik dank dan ook al mijn collega's waar ik de afgelopen jaren met veel plezier mee heb samen gewerkt en vooral ook mijn promovendi.

Een speciaal woord van dank aan Henk Schmidt en Wim Gijselaers, mijn eerste leermeesters, mijn promotoren. Van hen heb ik geleerd wetenschappelijk te schrijven. Op het goede moment kwam ik terecht in een goede groep en de goede naam en faam van mijn promotoren hebben mij enorm geholpen mijn weg te vinden in het onderzoek op het gebied van probleemgestuurd onderwijs. Dank aan Cees van der Vleuten, Albert Scherpbier en Jeroen van Merriënboer voor alle kansen die jullie mij gaven om me binnen de vakgroep en de School of Health Professions Education verder te ontwikkelen. Ik hoop dat ik nog veel van jullie mag leren.

Dank aan alle mensen die er de afgelopen jaren waren om mij en mijn gezin te steunen. Ik denk daarbij aan onze hulp, onze oppassen en mijn familie en in het bijzonder aan mijn schoonmoeder, mijn broer, mijn zus en mijn ouders die er allemaal zijn voor mij en mijn gezin als dat nodig is. Jullie zorgen er voor dat ik steeds met veel plezier kan werken. Dank aan Jos en onze kinderen, Wout, Gijs en Lieke. Ik ben dankbaar dat jullie er zijn.

Tot slot dank aan iedereen die hier vandaag aanwezig is bij mijn oratie.

Ik heb gezegd. 


\section{Referenties}

Aarnio, M., Lindblom-Ylänne, S., Nieminen, J. \& Pyörälä, E. (2012). Dealing with conflicts on knowledge in tutorial groups. Advances in Health Sciences Education, DOI 10.1007/s10459o12-9366-z.

Albanese, M.A. \& Mitchell, S. (1993). Problem-based learning: A review of literature on its outcomes and implementation issues. Academic Medicine, 68, 52-81.

Anderson, T. \& Shattuck, J. (2012). Design-Based Research: A decade of Progress in Education Research? Educational Researcher, 41, 1, 16-25.

Barrows, H.S. \& Tamblyn, R.M. (1980). Problem-based learning. An approach to Medical Education. New York: Springer.

Berliner, D.C. (2002). Educational research: The hardest science of all. Educational Researcher, $31,8,18-20$.

Boeckaerts, M. \& Cascallar, E. (2006). How far have we moved toward the integration of theory and practice in self-regulation? Educational Psychology Review, 18, 199-210.

Bransford, J.D. \& Schwartz, D.L. (1999). Rethinking Transfer: A Simple proposal with multiple implications. Review of Research in Education, 24, 61-100.

Budé, L., Imbos, Tj., Van de Wiel, M.W.J., Berger, M.P.F. (2009). The effect of directive tutor guidance in problem-based learning of statistics on students' perceptions and achievement. Higher Education, 57, 23-26.

Capon, N. \& Kuhn, D. (2004). What's So Good About Problem-Based Learning? Cognition and Instruction, 22, 1, 61-79.

Chi, M.T.H. (2009). Active-Constructive-Interactive: A Conceptual Framework for Differentiating Learning Activities. Topics in Cognitive Science, 1(1), 73-105.

Cohen, E. (1994). Restructuring the classroom: Conditions for productive small groups. Review of Educational Research, 64, 1-35.

Cohen-Schotanus, J., Muijtjens, A., Schonrock-Adam, J., Geertsma, J. \& Vleuten, van der. C.P.M. (2008). Effects of conventional and problem-based learning on clinical and general competencies and career development. Medical Education, 42, 256-265. 
Colliver, J. A. (2000). Effectiveness of problem-based learning curricula: Research and theory. Academic Medicine, 75, 3, 259-266.

Cook, D.A., Bordage, G. \& Schmidt, H.G. (2008). Description, justification and clarfication: a framework for classifying the purposes of research in medical education. Medical Education, $42,2,128-133$.

De Jong, N., Verstegen, D.M.L., Tan, F.E.S. \& O Connor, S.J. (2012). A comparison of classroom and online asynchronous problem-based learning for students undertaking statistics training as part of a Public Health Masters degree. Advances in Health Sciences Education, DOI 10.1007/s/10459-012-9368-x.

De Leng, B.A., Dolmans, D.H.J.M., Wiel van der, M., Muijtjens, A.M.M. \& Vleuten, van der, C.P.M. (2007). How video cases should be used as authentic stimuli in problem-based medical education. Medical Education, 41, 2, 181-188.

Diemers, A.D., Dolmans, D.H.J.M., Verwijnen, M.G.M., Heineman, E. \& Scherpbier, A.J.J.A. (2008). Students' opinions about the effects of preclinical patient contacts on their learning. Advances in Health Sciences Education, 13, 5, 633-647.

Diemers, A.D., van de Wiel, M.W.J., Scherpbier, A.J.J.A., Heineman, E. \& Dolmans, D.H.J.M. (2011). Preclinical patient contacts and the application of biomedical and clinical knowledge. Medical Education, 45, 280-288.

Dillenbourg, P. (1999) What do you mean by collaborative learning? In: P., Dillenbourg (Ed.). Collaborative-learning: Cognitive and Computational Approaches. (pp.1-19). Oxford: Elsevier.

Dochy, F., Segers, M., Van den Bossche, P. \& Gijbels, D. (2003). Effects of problem-based learning: a meta-analysis. Learning and Instruction, 13, 5, 533-568.

Dolmans, D.H.J.M., Wolfhagen, H.A.P., van der Vleuten, C.P.M. \& Wijnen, W.H.F.W. (2001). Solving problems with group work in PBL: Hold on to the philosophy. Medical Education, 35, 884-89.

Dolmans, D.H.J.M., Gijselaers, W.H., Moust, J.H.C., Grave, de, W.S., Wolfhagen, H.A.P. \& Vleuten, van der C.P.M. (2002). Trends in research on the tutor in PBL: conclusions and implications for educational practice and research. Medical Teacher, 24, 2, 173-180. 
Dolmans, DHJM, De Grave, W., Wolfhagen, IHAP \& van der Vleuten, CPM. (2005). Problembased learning: Future challenges for educational practice and research. Medical Education, 39, $732-741$

Dolmans, D.H.J.M. \& Schmidt, H.G. (2006). What do we know about cognitive and motivational effects of small group tutorials in problem-based Learning? Advances in Health Sciences Education, 11, 321-336.

Dolmans, D.H.J.M., Wolfhagen, I.H.A.P. \& Ginns, P. (2010). Measuring approaches to learning in a problem based learning context. International Journal of Medical Education, 1, 55-60.

Dolmans, D.H.J.M. \& Tigelaar, D. (2012). Building bridges between theory and practice in medical education using a design-based research approach: AMEE guide no. 6o. Medical Teacher, 34, 1-10.

Gijbels, D., Dochy, F., Van den Bossche, P. \& Segers, M. (2005). Effects of problem-based learning: A meta-analysis from the angle of assessment. Review of Educational Research, 75, 1, 27-61.

Hean, S., Craddock, D \& O'Halloran, C. (2009). Learning theories and interprofessional education: a user's guide. Learning in Health and Social Care, 8, 4, 250-262.

Hmelo-Silver, C.E. (2004). Problem-based learning: What and how students learn. Educational Psychology Review, 16, 3, 235-66.

Hoffman, K., Hosokawa, M., Blake, R., Headrick, L. \& Johnson, G. (2006). Problem-based learning outcomes at the University of Missouri-Columbia School of Medicine. Academic Medicine, 81, 7, 617-25.

Hofgaard Lycke, K., Grottum, P \& Stromso, H.I. (2006). Student learning strategies, mental models and learning outcomes in problem-based and traditional curricula in medicine. Medical Teacher, 28, 8, 717-722.

Johnson, D.W., Johnson R.T. \& Smith, K. (2007). The state of cooperative learning in postsecondary and professional settings. Educational Psychology Review, 19, 15-29.

Jones, A., McArdle, P.J. \& O'Neill, P.A. (2002). Perceptions of how well graduates are prepared for the role of pre-registration house officer: a comparison of outcomes from a traditional and an integrated PBL curriculum. Medical Education, 36, 16-25. 
Kamp, R.J.A., Dolmans, D.H.J.M., Van Berkel, H.J.M. \& Schmidt, H.G. (2012). The effect of midterm peer feedback on student functioning in problem-based tutorials. Advances in Health Sciences Education, DOI: 10.1007/s10459-012-9364-1.

Kirschner, P.A., Sweller, J. \& Clark, R.E. (2006). Why minimal guidance during instruction does not work: An analysis of the failure of constructivist, discovery, problem-based, experiential, and inquiry-based teaching. Educational Psychologist, 41, 2, 75-86.

Kirschner, F. Paas, F. \& Kirschner, P.A. (2009). A cognitive load approach to collaborative learning: United brains for complex tasks. Educational Psychology Review, 21, 31-42.

Kleijnen, J., Dolmans, D., Willems. J. \& Van Hout, H. (2012). Effectieve kwaliteitszorg vereist een systematische werwijze en een cultuur van flexibiliteit en open communicatie. Onderzoek van Onderwijs, 41, 7-11.

Knowles, M.S. (1975). Self-directed learning: A guide for learners and teachers. Chicago: Follet.

Leppink, J. (2012). Propositional manipulation for conceptual understanding of statistics. Unpublished PhD disseratation. Maastricht: Boekenplan Maastricht.

Loyens, S.M.M., Rikers, R.M.J. \& Schmidt, H.G. (2006). Students' conceptions of constructivist learning: A comparison between a traditional and a Problem-based learning curriculum. Advances in Health Sciences Education, 11, 4, 365-379.

Loyens, S.M.M., Magda, J. \& Rikers, R.M.J. (2008). Self-directed learning in problem-based learning and its relationship with self-regulated learning. Educational Psychology Review, 20, 411-427.

Meng, Ch. \& Heijke, H. (2005). Student time allocation, the learning environment and the acquisition of competencies. Internal report, Maastricht University: Research Centre for Education and the Labour Market, Faculty of Economics and Business Administration (OA-RM-2005/1E).

Moust, J.H.C., Van Berkel, H.J.M. \& Schmidt, H.G. (2005). Signs of erosion: Reflection on three decades of problem-based learning at Maastricht University. Higher Education, 50, 665-683.

Norman, G.R. \& Schmidt, H.G. (2000). Effectiveness of problem-based learning curricula: theory, practice and paper darts. Medical Education, 34, 721-728. 
Paavola, S., Lipponen, L. \& Hakkrainen, K. (2004). Models of innovative knowledge communities and three metaphors of learning. Review of Educational Research, 74, 557-76.

Paavola, S. \& Hakkarainen, K. (2005). The knowledge creation metaphor - An emergent epistemological approach to learning. Science \& Education, 14, 535-557.

Pressly, M., Wood, E, Woloshyn, V.E., Martin, V., King, A. \& Menke, D. (1992). Encouraging Mindful Use of Prior Knowledge: Attempting to Construct Explanatory Answers Facilitates Learning. Educational Psychologist, 27, 1, 91-109.

Prince, K.J.A.H., Van Eys, P.W.L.J., Boshuizen, H.P.A., Van der Vleuten, C.P.M., Scherpbier, A.J.J.A. (2005). General competencies of problem-based learning (PBL) and non-PBL graduates. Medical Education, 39, 394-401.

Regehr, G. (2010). It's NOT rocket science: rethinking our metaphors of research in health professions education. Medical Education, 44, 31-39.

Roebertsen, H., Moust, J.H.C. \& Savelberg, H.H.C. (2004). Traditioneel probleemgestuurd onderwijs vergeleken met probleemgestuurd onderwijs met studieteams: Enkele resultaten. Tijdschrift voor Hoger Onderwijs, 22, 3, 140-157.

Rotgans, J.I. \& Schmidt, H.G. (2011). Situational interest and academic achievement in the active-learning classroom. Learning and Instruction, 21, 58-67.

Ryan, R.M. \& Deci, E.L. (2000). Self-determination theory and the facilitation of intrinsic motivation, social development, and well-being. American Psychologist, 55, 1, 68-78.

Schlett, Ch.L., Doll, H., Dahmen, J., Polacsek, O., Federkeil, G., Fischer, M.R., Bamberg, F. \& Butzlaff, M. (2010). Job requirements compared to medical school education: differences between graduates from problem-based learning and conventional curricula. BMC Medical Education, 10, 1. http:/www.biomecentral.com/1472-6920/10/1.

Schmidt, H.G. \& Van der Molen, H.T. (2001). Self-reported competency ratings of graduates of a problem-based medical curriculum. Academic Medicine, 76, 5, 466-468.

Schmidt, H.G., Vermeulen, L. \& Molen, van der, H. (2006). Longterm effects of problem-based learning: A comparison of competencies acquired by graduates of a problem-based and a conventional medical school. Medical Education, 40, 562-67. 
Schmidt, H.G., Cohen-Schotanus, J. \& Arends, L. (2009). Impact of problem-based, active learning on graduation rates for 10 generations of Dutch medical students. Medical Education, 43, 211-218.

Schmidt, H.G., Cohen-Schotanus, J., Van der Molen, H., Splinter, T.A.W., Bulte, J., Holdrinet, R., Van Rossum, H.J.M. (2010a). Learning more by being taught less: a time-for-self-study theory explaining curricular effects on graduation rate and study duration. Higher Education, 60, 287-300.

Schmidt, H.G., van der Molen, H.T., Te Winkel, W.W.R. \& Wijnen, W.H.F.W. (2010b). Constructivist, problem-based learning does work: a meta-analysis of curricular comparisons involving a single medical school. Educational Psychologist, 44, 4, 227-249.

Schmidt, H.G., Rotgans, J. \& Yew, E. (2011). The process of problem-based learning: what works and why. Medical Education, 45, 8, 792-806.

Schmidt, H.G., Muijtjens, A.M.M., Van der Vleuten, C.P.M. \& Norman, G.R. (2012). Differential student attrition and differential exposure mask effects of problem-based learning in Curriculum Comparison Studies. Academic Medicine, 87, 4, 463-475.

Singaram, V.S, Vleuten, van der, C.P.M., Stevens, F. \& Dolmans, D.H.J.M. (2011). "For most of us Africans, we don't just speak": A Qualitative Investigation into Collaborative Heterogeneous PBL Group Learning. Advances in Health Sciences Education, 19, 2, 141-155.

Slavin, R. E. (1996). Research on cooperative learning and achievement: What we know, what we need to know. Contemporary Educational Psychology, 21(1), 43-69.

Springer, L., Stanne, M. E., \& Donovan, S. S. (1999). Effects of small-group learning on undergraduates in science, mathematics, engineering, and technology: A meta-analysis. Review of Educational Research, 69(1), 21-51.

Steinert, Y. Mann, K. Centeno, A., Dolmans, D., Spencer, J., Gelula, M. \& Prideaux D. (2006). A systematic review of faculty development initiatives designed to improve teaching effectiveness in medical education: BEME guide no 8. Medical Teacher, 28, 6, 497-526.

Ten Cate, O, Th., Kusurkar, R.A. \& Williams, G. (2011). How self-determination theory can assist our understanding of the teaching and learning processes in medical education. AMEE guide no. 59. Medical Teacher, 33, 961-973. 
Van Blankenstein, F.M., Dolmans, D.H.J.M., Vleuten, van der, C.P.M. \& Schmidt, H.G. (2011). Which cognitive processes support learning during small-group discussion? The role of providing explanations and listening to others. Instructional Science, 39, 2, 189-204.

Van den Bossche, P., Gijselaers, W. Segers, M., Woltjer, G. \& Kirschner, P. (2011). Team Learning: Building shared mental models. Instructional Science, 39, 283-301.

Van den Hurk, M. M., Wolfhagen, I. H. A. P., Dolmans, D. J. H. M., \& van der Vleuten, C. P. M. (1999). The impact of student-generated learning issues on individual study time and academic achievement. Medical Education, 33, 808-814.

Van der Linden, J., Erkens, G., Schmidt, H. \& Renshaw, P. (2000). Collaborative learning. In: R.J. Simons, J. van der Linden \& T. Duffy. New learning. pp 37-54 Kluwer: Dordrecht.

Van der Veken, J., Valcke, M., Muijtjens, A., De Maeseneer, J, \& Derese, A. (2008). The potential mof the inventory of learning styles to study students' learning patterns in three types of medical curricula. Medical Teacher, 30, 863-869.

Vernon, D.T.A. \& Blake, R.L. (1993). Does problem-based learning work? A meta-analysis of evaluative research. Academic Medicine, 68, 550-63.

Visschers-Pleijers, A.J.S.F., Dolmans, D.H.J.M., De Leng, B.A., Wolfhagen, I.H.A.P. \& van der Vleuten, C.P.M. (2006). Analysis of verbal interactions in tutorial groups: a process study. Medical Education, 40, 2, 129-137.

Walker, A. \& Leary, H. (2009). A problem-based learning meta analysis: Differences across problem types, implementation types, disciplines, and assessment levels. The Interdisciplinary Journal of Problem-based learning, 3, 1, 12-43.

Wirkala, C. \& Kuhn, D. (2011). Problem-Based Learning in K-12 Education: Is it effective and how does it achieve its effects? American Educational Research Journal, 48, 5, 1157-1186. 
